\title{
多様性適応力評価尺度の開発と適用の試み
}

\section{一日本ブラインドサッカー協会のワークショップを対象としてー ${ }^{\dagger}$}

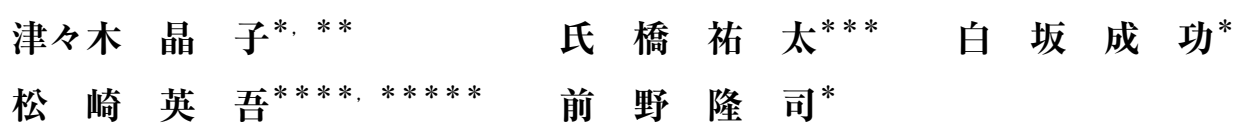

Scale of Diversity Adaptability:

Quantitative Research Based on Workshops Using Blind Soccer ${ }^{\dagger}$

\author{
Akiko TSUTSUKI ${ }^{*}, *$, Yuta UJIHASHI ${ }^{* * *}$, Seiko SHIRASAKA* \\ Eigo MATSUZAKI****,***** and Takashi MAENO*
}

\begin{abstract}
In this study we developed a "Scale of Diversity Adaptability" which measures the social skills to accept cultural diversity. First, we revealed the components of the evaluation measure of Diversity Adaptability. The components were collected by accumulating elements related to diversity using the methods of literature review, interview, and brainstorming. In addition, we built a tentative assessment by using the method of group discussion. Second, we decided the component names and defined the components, to clarify the relationship between the components. Third, we created questions regarding each component. Evaluation of validity of the scale was carried out by the following methods; individual item analysis, item-correlation analysis, path analysis, and confirmatory factor analysis. The reliability of the scale was evaluated by Crombach's alpha. As a result, the validity and reliability were evaluated for the 8 factors and 29 items scale. Using the developed scale, we measured the effect of the Blind-Soccer workshop. In particular, we carried out a test of factor scores before and after the workshop implementation. As a result, a significant increase was observed in the 6 factors. It is a force that shows personality, ambitions, bird's-eye view force, resilience, trust relationship building force, and communication. Altogether, the results of our study clearly showed that we have developed a "Scale of Diversity Adaptability" which can enable the evaluation of the
\end{abstract}

\footnotetext{
†原稿受付 2015年 4 月30日 原稿受諾 2015年 8 月17日

*慶應義塾大学大学院システムデザイン・マネジメント研究科币223-8526 神奈川県横浜市港北区日吉 4-1-1

**鹿屋体育大学東京サテライトキャンパス７112-0012＼cjkstart東京都文京区大塚 3-29-1

***旭化成株式会社 ₹101-0051 東京都千代田区神田神保町 1-105

****日本ブラインドサッカー協会 T169-0073 東京都新宿区百人町 1-23-7 新宿酒販会館 2 階

*****慶應義塾大学大学院システムデザイン・マネジメント研究科付属SDM研究所

干223-8526 神奈川県横浜市港北区日吉 4-1-1

* Graduate School of System Design and Management, Keio University, 4-1-1, Hiyoshi, Kohoku-ku, Yokohama, Kanagawa, Japan (223-8526)

** National Institute of Fitness and Sports in Kanoya, 3-29-1, Otsuka, Bunkyo-ku, Tokyo, Japan (112-0012)

*** Asahi Kasei Corp., 1-105, Kanda, Jinbocho, Chiyoda-ku, Tokyo, Japan (101-0051)

**** Japan Blind Football Association, 2F, Shinjuku-syuhan-kaikan, 1-23-7, Hyakunincho, Shinjuku-ku, Tokyo, Japan (169-0073)

***** Graduate School of System Design and Management Laboratory, Keio University, 4-1-1, Hiyoshi, Kohoku-ku, Yokohama, Kanagawa, Japan (223-8526)
} 
current situation and measures related to adaptability. Furthermore, we were able to confirm its usefulness. By using this scale as a standard assessment tool, it is believed that it is possible to contribute to the development of society as a whole through encouraging diversity adaptability.

Key words : Cultural Diversity, Diversity Adaptability, Scale, Blind-Soccer, Workshop

\section{1.はじめに}

グローバル化・ネットワーク化の進展に伴 い, 様々な意味での多様性の重要性が多方面 で指摘されている ${ }^{1)-3)}$. 多様性とは, 性別, 年歯, 人種・民族, 障がいの有無, といった 特徴だけではない. Jacksonら ${ }^{4)}$ は, それは相 互関係を持つメンバーの間の個人的な属性の 分類であり，その人を知った上で明らかにな る属性, 個性, 知識, 価值観, 教育, 職歴な どを含むと述べている. Fleming $5^{5)}$ は, ブ レークスルーに到達するために多様性が重 要であることを示している. また, Cox ら ${ }^{6)}$ は, 人材の多様性が, コスト, 資源獲得, マー ケティング, 創造性, 問題解決という複数の 分野で企業に競争優位を与えることを明らか にしている. 現在, 多くの企業が, 国際規 格であるISO26000「社会的責任の手引き」7) に基づき, ダイバーシティ・マネジメント（多 様性施策）への取り組み堛広く実施してい る.ダイバーシティ・マネジメントとは, これ までの慣習にとらわれずに, ジェンダー, 国籍, 年齢などの多様な属性や価值観を活用して, ビ ジネス環境の変化に迅速かつ柔軟に対応し, 企 業の競争力と社会的評価を高め, また個人の幸 せを実現しようとするマネジメント・アプロー チである ${ }^{9)}$. NTTコム オンライン・マーケティ ング・ソリューション株式会社が2010年に実施 した「ダイバーシティ・マネジメント調査」に よると, いずれのダイバーシティ・マネジメン トに取り組んでいない企業は 1 割にとどまり, 9 割の企業が何らかのダイバーシテイ施策を実 施している ${ }^{10)}$. しかし, これらの調査結果は, ダイバーシティという考え方の周知が不十分で あることや, その理解や意識が高まりにくいと
いった問題点を示している. 馬越 ${ }^{9)}$ は, 多様 な人材がそれぞれの持前で自分の能力をのびの びと発揮することが, 企業の競争力と社会的砲 火を高め, 経済を活性化し, 同時に, 組織の中 で働く個人にとっても自己の実現に通じてい く，という好循環をもたらすことを指摘してい る.

つまり，“多様な人材が集まる中でも自らの 個性を発揮し物事を達成する力”, すなわち “多 様性適応力”の育成が必要と考えられる.

スポーツ産業においては, 2020年の東京オリ ンピック・パラリンピックに向けて, スポーッ を越えた様々な社会課題の解決が期待されてい る. プラチナ社会研究所・レガシー共創協議会 ${ }^{11)}$ は, 社会課題解決のためのレガシーとして, 全 員が能力と個性を発揮し, 活躍する社会のビ ジョンを揭げている. 永浜 ${ }^{12)}$ は, 障がい者スポー ツ種目の実施及び講義が, 障がいのある人や障 がい者スポーツに対する意識が肯定的に変化す ることを明らかにしている。秋政ら ${ }^{13)}$ は, 車い すダンスの体験が, 車いすを身近な器具と認識 し, 障がいや障がい者への理解を深めることを 示している. 安井 ${ }^{14)}$ は, 車いすバスケットボー ルの体験をした子どもたちが，障がい者を「自 分と違わない」存在として捉えるようになった ことを明らかにしている. NPOユニバーサル イベント協会 ${ }^{1516)}$ は, ノーマライゼーションに 基づいたユニバーサルスポーツの普及や発展 の可能性を提案している. ノーマライゼーショ ンとは, 高齢者も障がい者も子どもも女性も男 性も, すべての人々が, 人種や年齢, 身体的条 件に関わりなく, 自分らしく, したい仕事や社 会参加ができるチャンスを平等に与えられるこ とが当たり前な共生社会のありかたを指してい る. また, 小林 ${ }^{17)}$ は, 共通ルールによって多様 
な文化を収束できる可能性のあるスポーツは, グローバル化に伴う，スポーツによる国際開発 に有効であることを示している.例えば, スポー ツを通じて異なる民族が相互に理解を深めるこ とによって，異民族間相互のコミュニケーショ ン促進へ繋がっていくと考えられている。これ らは, スポーツそのものが, 多様性に適応する 力を高める有効なツールであることを示唆して いる.

スポーツによるダイバーシティ・マネジメン トの取り組みに, ブラインドサッカーをモチー フにしたワークショップがある. 日本ブライン ドサッカー協会が, 多様性理解という観点で構 成し，企業や教育機関において展開している. このワークショップは, ボランティア精神, 障 がい者理解, チームワーク, 個性の尊重, コミュ ニケーションといった能力が向上するよう設計 されている. しかし，こうした能力を定量的に 評価する方法が存在しなかったため, その効果 を数值的に実証しにくいという点が課題となっ ている. ブラインドサッカー以外にも, 多様性 を活かして組織の構成員たる個人の意識・能力 を育成し, ダイバーシティ・マネジメントを成 功させることの重要性が認識されており, これ までに様々な取り組みが行なわれている。 しか し，そうした取り組みに扔ける個人の意識・能 力の変化を評価する方法がこれまで開発されて いなかったため, これらの定量化がなされてい なかった。

そこで, 本研究では, 多様性に対する個人の 適応力に関わる現状や施策の評価を可能にする ために, 個人の多様性に対する適応力を測定で きる “多様性適応力評価尺度”を開発し，その 有用性を確認する。 尺度の開発においては, 先 行研究の方法に基づき尺度をデザインし, 統 計学的にその妥当性と信頼性を評価する。ま た, 開発した多様性適応力評価尺度を適用して 日本ブラインドサッカー協会が実施するワーク ショップの評価を行う．その結果, このワーク ショップでは, 多様性適応力が向上することを 明らかにする。

\section{2. 先行研究と本研究の目的}

これまで, 多様性への配慮という視点から, 複数の尺度が開発されている， $\mathrm{WHO}^{18)}$ は, 日 常生活で生じる様々な問題や要求に対して, 建 設的かつ効果的に対処するために必要な能力 として，10のライフスキルを示している，菊 池 ${ }^{19)}$ は, 対人関係での円滑なかかわりを作り 出す社会的スキルの評価尺度を開発している. Montei ${ }^{20)}$ は, マイノリティに対する配虑を測 定する指標を開発している. Neville ${ }^{21)}$ は, 人種 に対する偏見のなさを評価する尺度を開発して いる. スポーツ心理学分野においては, スポー ツで獲得した心理的スキルが日常生活において どのように役立つかを明らかにする研究が多く 行われている。 上野ら ${ }^{22)}$ は, 社会的スキルを個 人的スキルと対人的スキルに分類した尺度を開 発している. 大获ら ${ }^{23)}$ は, サッカー選手のライ フスキル評価尺度を開発している。また，日経 BPコンサルティング (2013)の「ダイバーシティ 診断」では, 700 社 2,500 人のベンチマーク調査 結果と比較分析を 9 テーマ45項目の調査によっ て実施している，9つのテーマ内容は，ビジョ ン, 組織風土, マネジメント, 人材育成, コミュ ニケーション, 処遇, 機会均等, やりがい・働 きがい, ワークライフバランスである，調査を 全体ベンチマークと比較することによって, 改 善が必要な項目を示すことができる.しかし， これらの先行研究では, 多様性の対象や測定で きる環境に様々な制約を設けていたり，企業の 取り組み具合を評価したりしているにとどまっ ている．幅広く多くの人を対象にした個々人の 多様性に対する適応力や多様性施策そのものを 測定する指標は存在しない. その結果として, 企業や教育機関が費用・労力を投資して実施し ている研修や授業といった施策の効果は実証さ れておらず，その比較検討も定性的にしかなさ れてこなかった.こうした先行研究を背景に, 本研究では, “多様性に対する適応力”とは何 かについて，概念の明確化を行い，それらを評 価できる尺度を開発するとともに，尺度の有用 
性を明らかにする。

\section{3. 多様性適応力評価尺度の開発}

\section{1 尺度の作成}

はじめに，本尺度によって測定を目指す構成 概念である, 多様性適応力とその理論的文脈の 概念化を行うために, 項目の収集と精査を実施 した．本研究では，トライアンギュレーション という視点から, 複数の研究技法を組み合わせ て，尺度の作成を行った。

手順 1 尺度の概念化 : 多様性適応力評価尺度 の構成要素の明確化

手順 2 構成要素の定義: 構成要素名を決め, 定義し, 構成要素間の関係性の明確化

手順 3 質問項目の作成：それぞれの構成要素 の質問項目の作成

まずは, 尺度の概念化を行うために, 要求に 基づいて多様性適応力評価尺度の構成要素を明 らかにした。構成要素は, 文献調査, ブレイン ストーミング，専門家へのインタビューによっ て収集した。文献調查は, ライフスキル, Kiss18, ATDS, CoBRAS, 学校生活スキル24)25) を対象に, 重要であると考えられる項目を抽出 した。これらの文献で開発された尺度は，他の 研究の評価指標として用いられており, 社会的 スキルを表す概念として重要であると考えられ る.

ブレインストーミングは慶應義塾大学大学院 に所属する学生50名を対象に，8つのグループ に分けて，「多様な人材が集まる中で個性を発 揮し, チームとして目標を達成する力とは」と いう議題のもと実施した. ブレインストーミン グとは, 参加者が例えば 1 時間程度クリエイ ティブなイマジネーションを働かせるために行 う会議の一種であり, 特定の問題についてアイ デアを出し合うものである. ブレインストーミ ングを実施することによって，これまで考えら れてこなかった独創的なアイデアが出され, 議 論が幅広く行われることが期待される ${ }^{26)}$. 参加 者は, 与えられたテーマから連想し, 自分のア イデアを出したり, 他人のアイデアを参考にし
たりしながら, 数多くのアイデアを生み出して いく. 各グループは, 考えたアイデアをポスター や付箋に書き込むことによって多様なアイデア を収集する。

専門家へのインタビューは, 日本ブラインド サッカー協会のダイバーシテイ事業部の 2 名を 対象に，1回90分を目安に実施し，自由記述に おいて多数の項目を収集した. 文献調査, ブレ インストーミング，インタビューを実施した結 果, 200以上の項目の収集を行った.

次に, 収集した項目について, 著者らと専門 家を交えた議論を実施し，親和図法を用いてグ ルーピングを行った. 親和図法は, 数多くのア イデアを, 情報の意味の近さに基づいてグルー プにする手法である ${ }^{27)}$ ，文献調查，ブレインス トーミング，インタビューによって収集した項 目を，1つずつ付箋に書き込み，著者らと専門 家を交えたチームで議論をしながら，意味の近 さ（親和性）に基づいて項目をグルーピングし, そのグループごとに, 特徵を表す名前を付けた. その後, グルーピングの過程を振り返りながら, 全体を眺め, 視点を変えて，グルーピングを繰 り返した。その結果, 親和図を用いたグルーピ ングは複数パターン作成された。 その中でも, 最も論理的に漏れなく重なりなく分解されたグ ルーピングを採用した.

その後, 抽出した構成要素間の関係性につい て整理した（図 1 )。多様性適応力 8 構成要素 とその分類, 収集された項目の関係図を図 1 に 示す. まず, 多様性適応力を大きく 2 つのグルー プに分類した。一つは，「個人が前提として持 つべき力」であり，もう一つは「チームが持つ べき力」である，2つのグループを，それぞれ 4 つの構成要素に分類し, 収集した項目を構成 要素別に整理してロジックッリーを作成した. ロジックッリーとは, 事象間をロジックによっ てッリー状に示す手法である。「個人が前提と して持つべき力」として「個性を発揮する力」「挑 戦意欲」「俯瞰力」「創造力」に分類でき,「チー ムが持つべき力」として「利他精神」「許容力」 「信頼関係構築力」「コミュニケーション力」に 
(8構成要素)

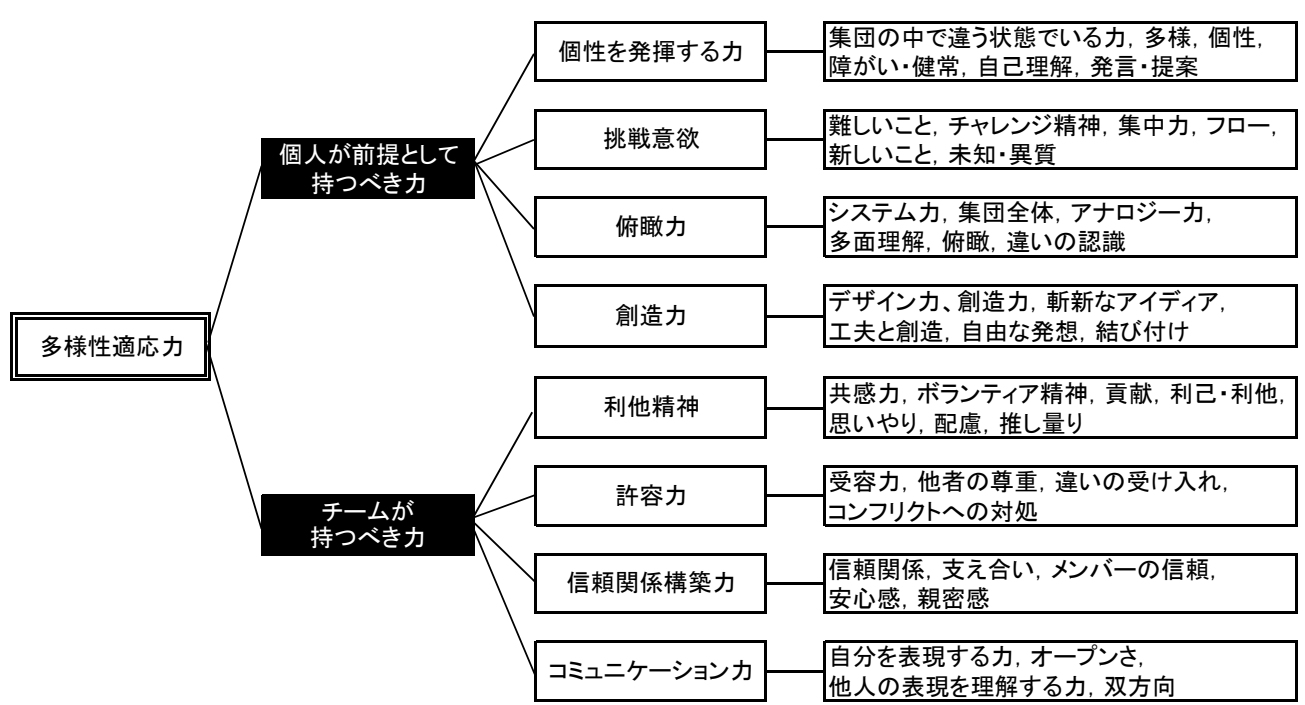

（多様性適応力の項目）

図 1 多様性適応力 8 構成要素の分類とそのロジックッリーおよび収集した項目の関係図

表 1 多様性適応力の構成要素名と定義

\begin{tabular}{ll}
\hline \multicolumn{1}{c}{ 構成要素名 } & \multicolumn{1}{c}{ 定義 } \\
\hline 個性を発揮する力 & 集団の中でも他のメンバーに合わせすぎることな, 自分の個性（長所や特技） \\
& を発揮する能力 \\
挑戦意欲 & 困難な課題, 初めての問題に対しても臆することなくチャレンジ精神を発揮し \\
& て取り組む力 \\
俯瞰力 & 物事全体を俯瞰的に捉え, 自分自身と他者の違いを理解する力 \\
創造力 & 既存の価值観に捉われず, 自由に発想することで新しいアイデアや方法を考える力 \\
利他精神 & 周囲の人々の気持ちに配虑して, 自分自身から相手に積極的に貢献する力 \\
許容力 & 自分とは異なる他者を認め, 相手を受け入れる力 \\
信頼関係構築力 & グループのメンバーと信頼関係を構築し, 相互に支え合う力 \\
コミュニケーション力 & 自らの考えを相手に伝え, 相手の考え方を正しく理解し, 相互に意思疎通する力 \\
\hline
\end{tabular}

分類できた. その後, 分類した 8 つ構成要素 に名前をつけ,構成要素の定義を行った(表 1$)$. 第 1 構成要素は,「自分の個性を発揮する」や「自 分の考えを積極的に発信していく」，「長所や良 さをチームで生かす」等がキーフレーズであっ たことから,「個性を発揮する力」と命名し,「集 団の中でも他のメンバーに合わせすぎることな く, 自分の個性（長所や特技）を発揮する能力」 と定義した．第 2 構成要素から第 8 構成要素に ついても, 複数のキーフレーズからグループ名
を命名した。

最後に，収集した項目を基に，それぞれの構 成要素に対応する 4 つの質問項目を設置し，合 計32項目を作成した（表 2)。各質問項目につ いて，それぞれ 7 段階（「まったくあてはまら ない」,「あまりあてはまらない」,「どちらかと いえばあてはまらない」,「どちらともいえな い」,「どちらかといえばあてはまる」,「かなり あてはまる」,「非常によくあてはまる」）から 一つ選ばせるようにした。このとき，「まった 
表2 多様性適応力の質問項目と因子負荷量

\begin{tabular}{|c|c|c|c|}
\hline \multicolumn{2}{|r|}{ 質問項目 } & $\begin{array}{c}\text { 32項目の } \\
\text { 因子負荷量 }\end{array}$ & $\begin{array}{c}\text { 29項目の } \\
\text { 因子負荷量 }\end{array}$ \\
\hline \multicolumn{4}{|c|}{ 個性を発揮する力 } \\
\hline 1 & 自分の個性を集団の中で発揮することが多い & 0.76 & 0.77 \\
\hline 2 & 多様な人が集まる中でも自分の良さを発揮できる & 0.64 & 0.64 \\
\hline 3 & 周りに気を使いすぎて自分の意見を言い出せないことが多い & 0.76 & 0.76 \\
\hline 4 & 様々な人集まる中で自分のアイデアを提案するのが苦手だ & 0.68 & 0.68 \\
\hline \multicolumn{4}{|c|}{ (⿻上丨 } \\
\hline 5 & 様々な場面で挑戦意欲を発揮している & 0.79 & 0.79 \\
\hline 6 & これまでにやったことのないことにも精力的に取り組める & 0.70 & 0.70 \\
\hline 7 & 普段から新しいことや異質なことを取り入れることの大切さを知っている & 0.58 & 0.58 \\
\hline 8 & 難易度が高い課題をとりあえずやってみようとは思わない & 0.60 & 0.59 \\
\hline \multicolumn{4}{|l|}{ 俯瞰力 } \\
\hline 9 & 普段から集団全体を見渡して運営することができている & 0.68 & 0.68 \\
\hline 10 & 一見関連性がないように思えることでも共通点を発見する力を持っている & 0.56 & 0.56 \\
\hline 11 & 物事を俯瞰的に捉えることの大事さを知っている & 0.53 & 0.52 \\
\hline 12 & 物事を一面的に理解してしまうことが多い & 0.52 & 0.51 \\
\hline \multicolumn{4}{|l|}{ 創造力 } \\
\hline 13 & 人が思いつかないような斬新なアイディアを出すことが多い & 0.75 & 0.75 \\
\hline 14 & 色々と工夫して新しい物を作り出す力を持っている & 0.77 & 0.77 \\
\hline 15 & 今までの価值観に捉われずに自由に発想することの大事さを知っている & 0.61 & 0.60 \\
\hline 16 & 他分野の事例を自分に結び付けて考えるのは苦手だ & 0.70 & 0.70 \\
\hline \multicolumn{4}{|l|}{ 利他精神 } \\
\hline 17 & 常に周囲の人々の気持ちに配慮している & 0.52 & 0.51 \\
\hline 18 & 周りの人を思いやりながらチームに貢献できる & 0.79 & 0.83 \\
\hline 19 & 他人の考えていることを推し量るのは苦手だ & 0.48 & 0.46 \\
\hline$※ 20$ & チームのメンバーに気を配ることはあまり大事ではないと思う & 0.43 & - \\
\hline \multicolumn{4}{|l|}{ 許容力 } \\
\hline 21 & 例え嫌いな人と同じチームになったとしても上手くやっていけることが多い & 0.61 & 0.63 \\
\hline 22 & メンバー間で不和が起きても仲を取り持って物事を進めていくことができる & 0.64 & 0.65 \\
\hline$※ 23$ & それぞれのメンバーが持つ違いを尊重することはさほど大事ではないと思っている & 0.37 & - \\
\hline 24 & 自分と他人との違いを受け入れるのは苦手だ & 0.59 & 0.57 \\
\hline \multicolumn{4}{|c|}{ 信頼関係構築力 } \\
\hline 25 & 色々な人と信頼関係を構築できることが多い & 0.72 & 0.75 \\
\hline 26 & 仲間と支え合って物事を進めることができる & 0.60 & 0.60 \\
\hline$※ 27$ & チームのメンバーを信頼できないことが多い & 0.34 & - \\
\hline 28 & 同じグループの人に安心感を与えるのが苦手だ & 0.69 & 0.70 \\
\hline \multicolumn{4}{|c|}{ コミュニケーションカ } \\
\hline 29 & 自分の考えを相手に正しく理解してもらえることが多い & 0.59 & 0.59 \\
\hline 30 & 相手の表現を正しく理解することができる & 0.55 & 0.55 \\
\hline 31 & グループのメンバーと相互にコミュニケーションをとるのが苦手だ & 0.62 & 0.62 \\
\hline 32 & グループのすべてのメンバーに対してオープンになれないことが多い & 0.42 & 0.43 \\
\hline
\end{tabular}

※網掛けの $3 つ の$ 質問項目 $20,23,27$, 基準值0.5以下でかつ, 専門家と議論の上, 多椂性適応力の重要な概念と して必要ではないと判断した項目

くあてはまらない」が 1 点, 「非常によくあて はまる」が 7 点となるように得点を割り当てた.

\section{2 尺度の評価}

作成した多様性適応力の質問項目を評価する ために，項目評価と尺度評価を実施した，対象 
は, 大学生・大学院生165名とし, 定量的なデー 夕を収集するために, アンケート調査を行っ た. 項目評価としては, 個別項目分析（注 1), 項目一全体相関分析 (注 2), パス解析（注 3) を実施した。尺度評価としては，妥当性と信頼 性の評価を行った，妥当性は構成概念妥当性 を評価し，信頼性はCrombachの $\alpha$ 係数によっ て内的整合性を評価した。アンケート調査を実 施した165名のうち117名（平均年齢24.6歳）か ら有効回答を得た。分析は, 統計解析ソフト SPSS Amos Version 20.0.0.1を用いて行った.

個別項目分析の結果, 回答にフロア効果・天 井効果が見られた項目はなかった. 項目一全体 相関分析の結果, 項目と合成変数の相関は有意で あり, 他の合成変数との間により高い相関を示 した項目はなかった。 パス解析においては, 因 子負荷量によって対応関係の強さを評価する ${ }^{28)}$. それぞれの潜在変数一観測変数間の因子負荷量 を算出し, 基準值が 0.5 以上であることが推奨 される ${ }^{29)}$. 表 2 にパス解析後の32項目の因子負 荷量を示した. 以下の 5 項目が基準值を下回っ ていた.

質問19「他人の考えていることを推し量るのは 苦手だ (0.48)」

質問20「チームのメンバーに気を配ることはあ まり大事ではないと思う $(0.43) 」$

質問23「それぞれのメンバーが持つ違いを尊重 することはさほど大事ではないと思っている (0.37)」

質問27「チームのメンバーを信頼できないこと が多い (0.34)」

質問32「グループのすべてのメンバーに対して オープンになれないことが多い $(0.42) 」$

これらの項目について, 専門家と議論し, 当 該構成要素にとって重要な構成概念であると判 断した質問19及び質問32の項目は削除せず，そ れ以外の 3 項目は削除した。 以上の手順で， 8 構成要素29項目の尺度を再構成した。この 8 構 成要素29項目のモデルについて, パス解析を
行った結果, 質問19及び質問32の項目を除いた, すべての項目について，パス係数は有意である ことが確認された．29項目の因子負荷量を表 2 に示した.

次に, この 29 項目の尺度について, 妥当性の 評価を行った。妥当性とは, 観察された尺度ス コアの差異が, 系統誤差や偶然誤差ではなく, 測定している特性における対象間の真の差異を 示している程度であると定義できる ${ }^{30)}$ ．妥当性 の評価としては，構造方程式モデリングを用い た確認的因子分析を実施することによって，構 成概念妥当性（注4）を評価した。確認的因子 分析とは, 仮説因子モデルの構成概念妥当性を 検証するための因子分析である．構造方程式モ デリングによって算出される適合度指標には, $\chi^{2} / \mathrm{df}$ (注 5), RMSEA（注6), CFI（注7), GFI（注 8), AGFI（注 9), 及びAIC等がある. 本研究では，これらの適合度指標を総合的に判 断し, 多様性適応力の構成概念妥当性を検証し た。

確認的因子分析を行うために，パス図の作成 を行った。今回作成したパス図に関しては，8 つの構成要素を潜在変数, 29の質問項目を観測 変数とした．潜在変数から観測変数へとパスを 引き，8つの潜在変数間で共分散を仮定し，共 分散を表す双方向の矢印によって結んだ。確認 的因子分析の結果，モデルの適合度指標は $\chi^{2}$ $\angle \mathrm{df}=1.970, \mathrm{RMSEA}=0.091 、 \mathrm{CFI}=0.774$ 、 GFI $=0.725, \quad$ AGFI $=0.657, \quad$ AIC $=859.429$ と なり， $\chi^{2} / \mathrm{df}$, RMSEAは基準值を満たした. これより, 適合度は許容範囲内であると考えら れる，作成したパス図を図2に示す。また， 3 項目を削除する前の 8 構成要素32項目の尺度 についても同様に確認的因子分析を実施した 結 果, $\chi^{2} / \mathrm{df}=1.932 、 \mathrm{RMSEA}=0.090, \mathrm{CFI}$ $=0.746, \quad \mathrm{GFI}=0.707, \quad \mathrm{AGFI}=0.645, \quad \mathrm{AIC}=$ 1026.453となった. RMSEA, CFI, GFI, AGFI, AICの值において，8構成要素29項目のモデル の方が, 32項目のモデルよりも妥当な適合度を 示した. 8 構成要素29項目の尺度がより妥当で あることが判明したため，こちらの尺度を採用 


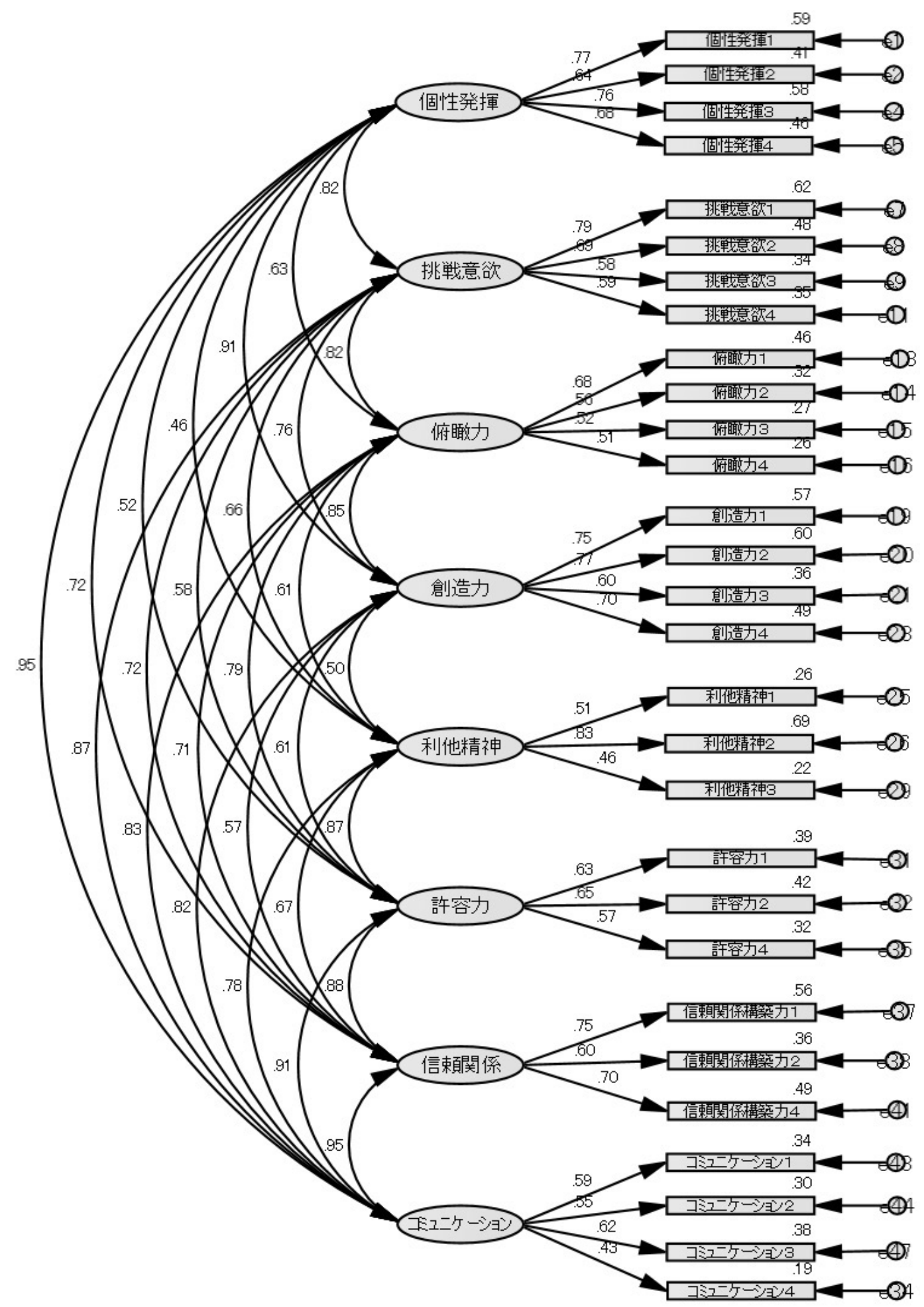

目2多様性適応力 8 構成要素 29 項目モデルのパス図 
表3 ワークショップの流れ（180分）

\begin{tabular}{|c|c|c|c|c|c|c|c|c|}
\hline 10分 & 20分 & 10分 & 10分 & 30分 & 30分 & 30分 & 30分 & 10分 \\
\hline 事前評価 & 導入 & $\begin{array}{l}\text { ウォーミン } \\
\text { グアップ(1) }\end{array}$ & $\begin{array}{l}\text { ウォーミン } \\
\text { グアップ(2) }\end{array}$ & $\begin{array}{c}\text { 基本 } \\
\text { ワーク (1) }\end{array}$ & $\begin{array}{c}\text { 基本 } \\
\text { ワーク (2) }\end{array}$ & $\begin{array}{c}\text { 基本 } \\
\text { ワーク (3) }\end{array}$ & 振返り & 事後評価 \\
\hline 多様性適応 & 研修概要/ & コミュニ & コミュニ & \multicolumn{3}{|c|}{ 基本ワークを繰り返す。チームビル } & ワークでの & 多様性適応 \\
\hline 力評価尺度 & 諸注意/な & ケーション & ケーション & \multicolumn{3}{|c|}{ ディングに必要な要素を参加者の } & 気づき、学 & 力評価尺度 \\
\hline による自己 & ぜブライン & 1 ：声を出 & $2:$ ブラサ & \multicolumn{3}{|c|}{ チームの様子に合わせて織り込んで } & び、「チー & によ \\
\hline 評価 & $\begin{array}{l}\text { ドサッカー } \\
\text { なのか? / } \\
\text { デモンスト } \\
\text { レーション }\end{array}$ & $\begin{array}{l}\text { すことの大 } \\
\text { 切さ }\end{array}$ & $\begin{array}{l}\text { カ流コミュ } \\
\text { ニケーショ } \\
\text { ンの定義 }\end{array}$ & \multicolumn{3}{|c|}{$\begin{array}{l}\text { いく。基本ワークの中で、気づきや } \\
\text { 試行錯誤をすることによって、チー } \\
\text { ムがトランスフォームし、成果があ } \\
\text { がる。同時に、チームメイト同士の } \\
\text { 関係性も変化する }\end{array}$} & $\begin{array}{l}\text { ムとは何 } \\
\text { か? ににつ } \\
\text { いて振返り }\end{array}$ & 評価 \\
\hline
\end{tabular}

することとした．

最後に, Crombachの $a$ （注10）を用いて内 的整合性を評価した， $a$ の值が 0.6 以下の場合 は，一般的には内部一貫性による信頼性は満足 できないことを示している，尺度の信頼性を 検証する際, その信頼性の低さから再検討を 要する目安を0.50未満としている ${ }^{31) 32)}$. 尺度の 29項目について，それぞれの構成要素ごとに Crombachの $a$ 係数, 修正済み項目合計相関, 項目が削除された場合のCrombachの $a$ を算出 した. 修正済み項目合計相関は, その項目の得 点と, それ以外の項目の合計得点との相関係数 である１つの尺度を構成するときには，そこ に含まれる項目群がある程度同じ方向性を持つ 必要がある. そのため, この值が低い数值を取 る場合には, その項目を尺度として含めるのは 望ましくない. 一方, 項目が削除された場合の Crombachの $a$ とは, 「その項目を除いた場合」 の $\alpha$ 係数を表す. 修正済み項目合計相関, 項目 が削除された場合のCrombachの $\alpha$ が著しく高 くなる項目に注意し, それぞれの尺度を分析し た. その結果, Crombachの $a$ 係数は, 個性を 発揮する力 $a=0.80$, 挑戦意欲 $a=0.75$, 俯瞰 力 $a=0.65$, 創造力 $a=0.80$, 利他精神 $a=0.64$, 許容力 $\alpha=0.65$, 信頼関係構築力 $\alpha=0.72$, コ ミュニケーション力 $\alpha=0.62$, であった. 俯瞰 力, 利他精神, 許容力, コミュニケーション力 の 4 項目については $a=0.70 に は$ 満たなかった ものの, 再検討の目安とされる $\alpha=0.50$ は大き く上回り, 尺度の信頼性に関して適切な值を得
たと判断した．以上のように，8構成要素29項 目の尺度の妥当性と信頼性が評価されたため, 提案した多様性適応力測定尺度は有効であると 考えられる。

\section{4. 開発した多様性適応力評価尺度の適用}

\section{1 日本ブラインドサッカー協会のワーク}

\section{ショップ}

日本ブラインドサッカー協会は, ブラインド サッカーを通じて, 視覚障がい者と健常者が当 たり前に混ざり合う社会を実現することをビ ジョンとした団体である. 主な活動として, ブ ラインドサッカーの強化・育成・普及・大会運 営事業の他, 企業や教育機関に晴眼者を対象と したワークショップを実施している ${ }^{33)}$.

ブラインドサッカーは, 全盲の選手がプレー するフットサル (5 人制サッカー) で, ゴール キーパーは目が見える晴眼者が行う。通常, 晴 眼者は, 情報の 8 割程度を視覚から得ていると 言われる，視覚情報を制限した状態で行うブラ インドサッカーは, 視覚情報に頼らないコミュ ニケーションが必要とされる，ワークショップ においては, 参加者のコミュニケーションスキ ル, チームビルディング, リーダーシップ, ボ ランティア精神, 障がい者理解, が向上するこ とを目標とし，参加者がそれらを段階的かつ体 系的に学べるようプログラムが組まれている. 具体的には， $3 \sim 6$ 人でグループを作り，アイ マスクを装着して視覚が完全に制限された状態 を作る。それぞれのグループで音が鳴るサッ 
カーボールを用いて, 音を頼りにボールを見つ ける, 相手に渡す, 攻撃と守備に分かれてのド リブル突破とそれを防ぐディフェンス等のワー クの組み合わせをあわせて 3 時間ほど行う（表 3). 3 時間の詳細は以下の通りである. ワー クショップの始めの10分は, 多様性適応力評価 尺度を用いた自己評価を行う. 次の 20 分は, 導 入として, 研修の概要説明, 諸注意を行い, な ぜブラインドサッカーなのかを考えさせ, 視覚 障害をもった選手によるデモンストレーション を行う。 その後, ウォーミングアップを行い, 基本ワークを行う. ウォーミングアップとして は, 声を出すことの大切さ (10分)、ブラサカ 流コミュニケーションの定義（10分）を行う. 基本ワークとしては, 参加者のチームの様子に 合わせて，チームビルディングに必要なワーク を行う $(30$ 分 $\times 3$ 回). 基本ワーク終了後, ワー クでの気づきや学びについて, 振り返り (30分) を行い, 最後に多様性適応力評価尺度を用いた 自己評価を再度行う (10分). しかし, 前述し たとおり,このワークショップの問題点は, ワー クショップによって本当に掲げる能力が向上す るのか, その効果を定量的に測定評価できる指 標がないことであった，そのため，協会自身も 展開するプログラムの有効性を定量的に実証で きなかった.

\section{2 方法}

本研究で開発した多様性適応力評価尺度を用 いて，実際に評価することによって，ワーク ショップの効果と参加者の多様性適応力を測定 できる。また，開発した多様性適応力評価尺度 の妥当性について検証し考察を深めることがで きる. 本研究では, 日本ブラインドサッカー協 会が実施するワークショップに参加した大学 生・大学院生を対象とした.

・A大学大学院システムデザイン・マネジメン 卜研究科の大学院生

(以下, $A$ 大学大学院, $\mathrm{n}=54$, 平均年齢 31.0 歳 \pm 9.5 , 男性38名, 女性16名)

・A大学総合政策学部・環境情報学部でスポー
ツ科学・体育の講義を履修する大学生

(以下, $\mathrm{A}$ 大学, $\mathrm{n}=34$, 平均年䶡19.4歳 \pm 1.2 , 男性18名, 女性16名)

・B大学 (国立大学) で開催された講義「アル タナティブ・スポーツ」を履修する大学生

(以下, $\mathrm{B}$ 大学, $\mathrm{n}=29$, 平均年齢19.1歳 \pm 0.7 , 男性20名, 女性 9 名)

A大学大学院は, 社会人大学院であり, 勉学 やグループワークに対して強いモチベーション を持った人々の集まりである.A大学大学院の 平均年齢は, $\mathrm{A}$ 大学, $\mathrm{B}$ 大学に比べると高い特 徵がある. A大学, B大学の対象者は, 大学の 必修科目あるいは選択科目により履修している 講義の参加者である.

ブラインドサッカーのワークショップの実施 直前及び直後に, 多様性適応力評価尺度 8 因子 29項目のアンケートを実施し，117名の有効回 答を得た.

\section{3 分析}

回収したアンケート29項目の因子得点につい て平均点を算出した. その後, 3 つの分析を行っ た.

1 ）ワークショップ実施前後の平均点を比較 し, 因子別の $\mathrm{t}$ 検定による有意差を確認し た。

2) A大学大学院, A大学, B大学のグループ に分けて，ワークショップ実施前の因子に ついて, 一元配置分散分析及び多重比較を 行い, 有意差を確認した

3） 2 ）のグループ別に， ワークショップ実施 前後の因子得点の $\mathrm{t}$ 検定を行い, 有意差を 確認した.

\section{4 結果}

1 ）ワークショップ実施前後で 3 グループの 合計の因子得点の $\mathrm{t}$ 検定を行った結果, 個性を 発揮する力 $\lceil\mathrm{t}=-3.78, \mathrm{p}<.01 」$, 挑戦意欲 $\lceil\mathrm{t}$ $=-3.50, \mathrm{p}<.01 」$, 俯瞰力 $\lceil\mathrm{t}=-3.19, \mathrm{p}<.01 」$, 許容力 $\lceil\mathrm{t}=-2.65, \mathrm{p}<.01 」$, 信頼関係構築力 $\lceil\mathrm{t}$ $=-2.50, \mathrm{p}<.05\rfloor$, コミュニケーション力 $「 \mathrm{t}$ 
表 4 ワークショップ実施前後の因子得点の平均値と標準偏差および $\mathrm{t}$ 検定の結果 $(\mathrm{n}=117)$

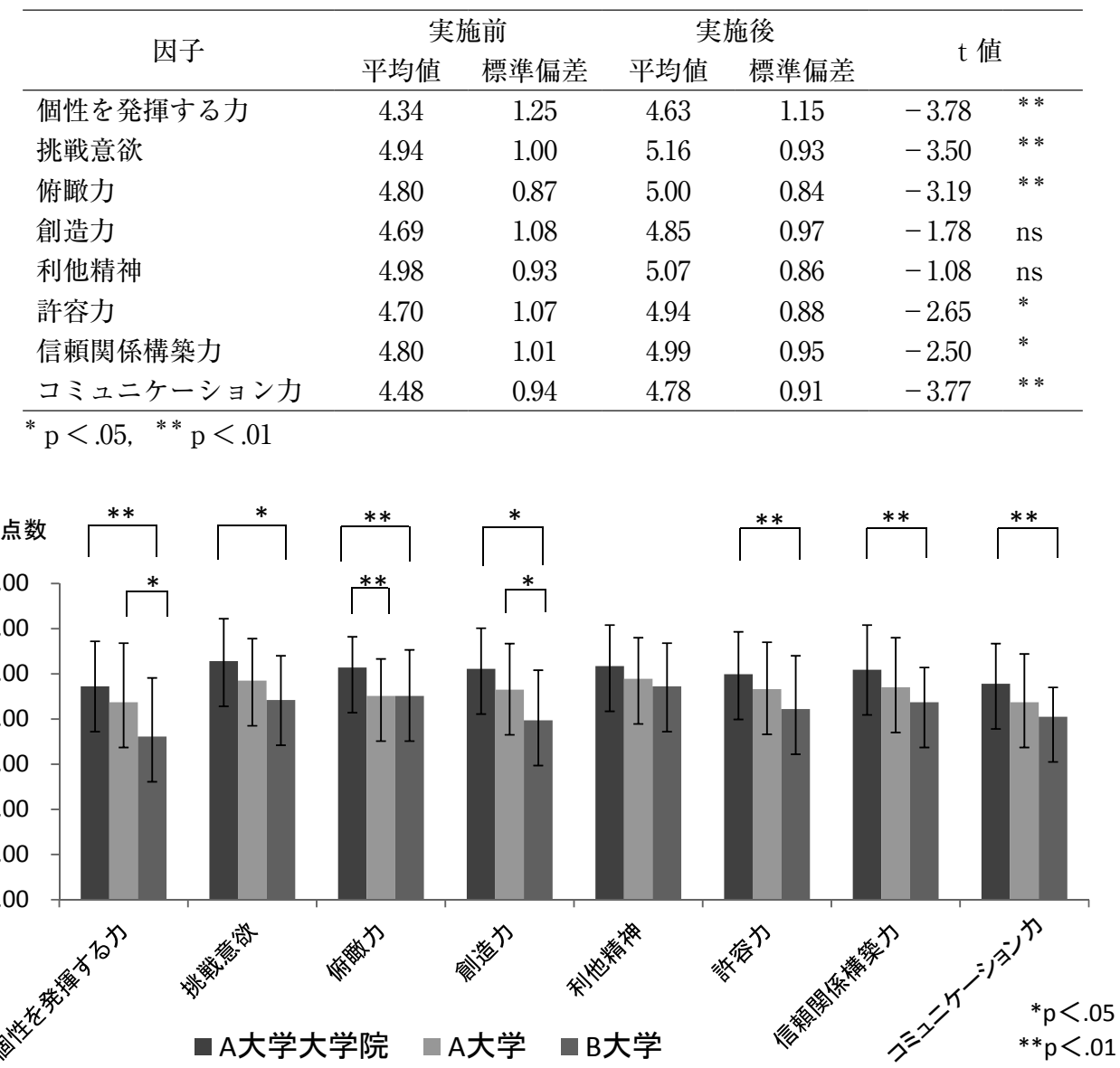

図 3 多様性適応力のグループ間比較

$=-3.77, \mathrm{p}<.01 」$, の 6 つの因子について, 有 意な上昇が見られた（表 4 ）。

2) A大学大学院, A大学, B大学のグルー プに分けて, ワークショップ実施前のグループ 間の比較を行った. 一元配置分散分析を行った 結果, 利他精神以外のすべての因子で有意差が 認められた. その後, 多重比較を行った結果, $\mathrm{A}$ 大学大学院と B大学間に, 個性を発揮する力 $(<.01)$, 挑戦意欲 $(<.05)$, 俯瞰力 $(<.01)$, 創造力 $(<.05)$, 許容力 $(<.01)$, 信頼関係構 築力 $(<.01)$, コミュニケーション力 $(<.01)$ の 7 因子に有意差が認められた. また、A大学 大学院と $\mathrm{A}$ 大学間には, 俯瞰力 $(<.01)$ に有 意差があった. A大学と B大学間には, 個性を
発揮する力 $(<.05)$, 創造力 $(<.05)$ に有意 差が認められた（図3）。

3 ）グループ別に実施前後の因子得点の $\mathrm{t}$ 検定を行った. その結果, A大学大学院では, 個性を発揮する力 $「 \mathrm{t}=-4.31, \mathrm{p}<.01 」$, 挑戦 意欲 $\lceil\mathrm{t}=-3.02, \mathrm{p}<.01 」$, 俯瞰力 $\lceil\mathrm{t}=-3.18$, $\mathrm{p}<.01 」$, 信頼関係構築力 $\lceil\mathrm{t}=-4.19, \mathrm{p}<.01 」$, コミュニケーション力 $「 \mathrm{t}=-3.02, \mathrm{p}<.01 」$, の 5 因子について有意差が確認され, B大学で はコミュニケーション力 $「 \mathrm{t}=-2.81, \mathrm{p}<.01 」$ のみ有意差が確認された，A大学では，いずれ も有意な差が認められなかった. 
表 5 A大学のワークショップ後の自由記述による感想 (一部抜粋)

\begin{tabular}{|c|c|}
\hline No & 参加者からの感想 \\
\hline 感想 1 & $\begin{array}{l}\text { ブラインドサッカーを体験してチームメイトを信頼する気持ちが大きくなったと思う．視覚と } \\
\text { いう大きな情報源を失った状態でスポーツを実践するには他人から伝えられる情報を理解する } \\
\text { 力，そして行動に移せる力が必要なのだと分かった。 }\end{array}$ \\
\hline 感想 2 & $\begin{array}{l}\text { ほとんど知らない人とボールで信頼関係を気づくことができる貴重な体験でした. 受け身にな } \\
\text { らずに, 積極的にコミュニケーションを図ることや, 自分の考えを相手に正確に伝えることが } \\
\text { どれだけ難しいことかを改めて感じました. }\end{array}$ \\
\hline 感想 3 & $\begin{array}{l}\text { 始める前から無理！怖い！という先入観しかなかったが, かなり楽しかった. 怖いことに変わ } \\
\text { りないが意外と「無理」ではなく, 集中すれば自分のチームのボールがどこにあるか, 誘導し } \\
\text { ている人がどこから声を出しているかもある程度分かった. }\end{array}$ \\
\hline 感想 4 & $\begin{array}{l}\text { 私は初対面の人とコミュニケーションをとるのが上手ではない方ですが, アイマスクをして視 } \\
\text { 界を遮ることによって, 聴覚が頼りになるので, 自分から声をかけることに普段より積極的に } \\
\text { なれた. }\end{array}$ \\
\hline 感想 5 & $\begin{array}{l}\text { 自分の存在を知らせる声や, 仲間を助ける声, ブラインドサッカーに必要な声は, 普通のサッカー } \\
\text { やフットサルにおいても, 重要な役割を果たすと思います. }\end{array}$ \\
\hline 感想 6 & このワークショップで自分が得られた一番大きなものは「人を信じる勇気」であると思う. \\
\hline 感想 7 & $\begin{array}{l}\text { 全く知らない人でも, その人を信じて自分の体を動かすことは信頼関係を築くとても大きな要 } \\
\text { 因になりました. }\end{array}$ \\
\hline
\end{tabular}

\section{5 考察}

以上の結果について，考察を行うとともに， ワークショップ講師に対するインタビューを行 なった．また，A大学のワークショップ後の自 由記述による感想も考察に加えた。

まず， 3 グループ合計の多様性適応力の 6 因 子についてワークショップ実施前後で有意差が 認められたことから, 日本ブラインドサッカー 協会のワークショップは, 多様性適応力を高め ることのできるワークショップであったと考 えることができる. ワークショップ講師から も, 能力の自己評価の向上は妥当な結果と考え られるというフィードバックを受けることがで きた. また, A大学のワークショップ後の自由 記述による感想 (表5) では, 本研究で明らか にした 8 因子につながる内容を確認できた。例 えば, 感想 1 に示す「ブラインドサッカーを体 験してチームメイトを信頼する気持ちが大きく なったと思う．視覚という大きな情報源を失っ た状態でスポーツを実践するには他人から伝え られる情報を理解する力, そして行動に移せる 力が必要なのだと分かった.」という感想には,
8 因子のなかの, 信頼関係構築力, コミュニケー ション力, 許容力, 利他精神, 個性を発揮する 力, 挑戦意欲の高まりにつながる気づきがある と考えられる．以下，感想 2 以降においても同 様に多様性適応力の自己評価の向上につながる 内容が確認された.

次に, 実施前の 3 大学・大学院の多様性適応 力の一部に有意差があったことから, 本尺度は グループ間の比較に利用できる可能性があるこ とがわかった. 全体としてA大学大学院の值が 高い傾向があるが, A大学大学院のみ, 学生の 過半数が社会人であり, 平均年齢が高いことが 影響したのかも知れない.このように，年齢な どの属性が多様性適応力に与える影響の研究へ と本研究を拡張できる可能性も示唆された.

また，グループごとに，ワークショップ実施 前後の多様性適応力の上昇に差があった原因と しては, 以下の点が考えられる. まず, A大学 大学院の大学院生は 54 名であったのに対し, A 大学の学生は34名, B大学の学生は 29 名と少な かったので，後者では人数が少なすぎた，す なわち, 3 大学・大学院比較におけるサンプル 
数の多少があったために有意な差が出なかった 可能性がある. また, 組織によって参加者のモ チベーションや資質が異なる可能性が考えられ る.このため, 人数を増やすとともに, 多様な 組織において多様性適応力を計測することに よって, 組織や属性等の違いが多様性適応力に 与える影響を解明することは今後の課題であ る。

また, 本研究では, 開発した多様性適応力評 価尺度を用いて，3 時間のプログラム前後にお ける自己評価の向上が見られたが，1 週間後, 1 力月後あるいは 3 力月後のような事後に自己 評価の変化がどのように表れるのかという長期 的な評価も今度の課題である.

また，本論文ではブラインドサッカーのみを 対象として多様性適応力の計測を試みたが，他 の活動への展開可能性も考えられる. 他のス ポーツへの拡張のみならず, アイデアを出す ためのワークショップやPBL (Project Based Learning）など, 様々な活動の評価への拡張 も考えられる.これらの展開は今後の課題であ る.また, 様々な社会単位（大学間・企業間・ 都市間）の集団の比較による多様性適応力の現 状把握を行うことも可能である. 本尺度を標準 的なアセスメントッールとして用いれば, 多様 性適応力の社会全体での育成に寄与することも 可能であると考えられる，ストレス，幸福度， その他の指標との関連性を明らかにすることも 今後の課題である.

\section{5. ま と}

本研究では, 多様性適応力に関わる現状や施 策の評価を可能にするために多様性適応力測定 尺度を開発し，ブラインドサッカーを対象にそ の有用性を確認した。すなわち, 多様な人材が 集まる中で自らの個性を発揮し共に物事を成し 遂げる力を定量的に測定する指標を提案し, 定 量的にその妥当性と信頼性を評価した。そし て, 人間の属性ごとに多様性適応力と, ワーク ショップ効果の測定を行い, 作成した尺度が有 用であることを確認した。
本研究によって得られた点を以下にまとめ る.

(1) 8 因子 29 項目から成り立つ多様性適応力 評価尺度を開発した。因子は，個性を発揮する 力, 挑戦意欲, 俯瞰力, 創造力, 利他精神, 許 容力, 信頼関係構築力, コミュニケーション力 の 8 づある.

(2) 本尺度をブラインドサッカーの事例に適 用し，活動前後やグループの差異を計測する手 法として使用できることを確認した。 なお，こ のたび行なったブラインドサッカーのワーク ショップによって向上したのは, 個性を発揮す る力, 挑戦意欲, 俯瞰力, 許容力, 信頼関係構

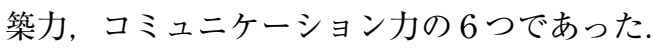

（注 1 ）それぞれの項目に対しての平均值，標準 偏差, 平均值 - 標準偏差, 平均值 + 標準偏差を 計算し, フロア効果, 天井効果を示す項目がな いかを検討した。 これによって, 得点が著しく偏 る項目の有無を調べ, 不適当な項目がないかを 検証する. 目安として, 各項目の回答に対する 平均值から標準偏差を引き算し, とりうる最低 值以下（1 以下）となるものはフロア効果, 平均 值から標準偏差を足し算し, とりうる最高值以 上（7 以上）となるものは天井効果があるとした. フロア効果, 天井効果がみられる項目は, 平均 值がリッカート尺度の中央地である 4 に近く, 分 散も左右に均等である項目と比較し，そもそも 項目自体に問題がある可能性が高いとされる。

(注 2) 項目全体得点と各質問項目との相関係数 を求め, 有意差のない項目は削除する。この理 由は, 同一の構成要素を測定するための項目に 関しては, 多少のばらつきは存在するとしても, その方向性に関してはある程度そろっている心゙ きと考えられるからである. その結果として, 同一の構成要素に属する項目間については質問 項目間の相関が他の構成要素に属する質問と比 較した際に高くなるはずである，仮に同一の構 成要素に属する項目間の相関が有意でなく, 且 つ他の構成要素の項目と相関が高かった際は項 目の削除・移動などが検討される。

（注 $3 ）$ 変数間にいくつかの因果を仮定し，共分 散行列や相関行列を基に因果推論を行う統計的 な分析手法である，本研究で用いた，構造方程 
式モデリング（共分散構造分析）とは, 直接観 測できない潜在変数を導入し, 潜在変数と観測 変数との間に因果関係を同定することにより社 会現象や自然現象を理解するための統計的アプ ローチである ${ }^{34}$.

（注４）構成概念妥当性とは, テストが測定をめ ざす概念に関する理論的予測が実際のデータに よって実証されるかどうかによって，テストの 妥当性を評価しようとする考え方である ${ }^{31}$.

（注５）共分散構造分析で最も基本的な適合度指 標の一つである $\chi^{2}$ 值を自由度で除したもの. $\chi^{2}$ 值はモデルがデータと適合しているかを確認す ることができる指標. 值が 0 に近いほどよい.

(注6) RMSEA とは, root mean square error of approximationの略であり，モデルの分布と真の 分布との乘離を 1 自由度当たりの量として表現 した指標である。一般に 0.05 以下であれば当ては まりが良く，0.1以上であれば当てはまりが悪い としている.

（注 7) CFIとは, Comparative Fit Indexの略で あり，独立モデルを基準に比較することでモデ ルの適合度を測る指標. 0.90 が一応の目安となる としているが, サンプル数が少ない時は, モデ ルの変数を増やした際に值が小さくなる.

（注８）モデルを直接評価する絶対適合度指標で あり,完璧なモデルを表す際は1.0の值を取る. 0.9 以上が目安とされているが, GFIが高ければ良 いモデルというわけではない.

（注９）adjusted GFIのことで, 自由度によって GFIを修正する指標. サンプル数が少ないと, 小 さな值を取ることが多い. Akaike's Information Criterion は統計モデルの複雑さとデータとの適 合度とのバランスを取るために使用される指標 であり, 複数のモデルを比較した際に, AICが 最小のモデルを選択すると，良いモデルが選択 できるとしている.

(注10) Crombachの $a$ 係数は次の式から算出され る. $a=$ 項目数 $/($ 項目数 -1$) \times\{1-($ 各項目の 分散の合計/合成值の分散)\}よって, $a$ は項目数 に比例する.

$$
\text { 付 記 }
$$

本研究は, 慶應義塾大学大学院博士課程学生 研究支援プログラムによる支援を受けて実施し た.

\section{参考文献}

1 ）厚生労働省,「外国人雇用状況」の届出状況ま とめ (平成26年10月末現在), 2015 .

2 ) 厚生労働省, 平成25年 障害者雇用状況の集計 結果, 2013.

3 ) 独立行政法人日本学生支援機構, 平成 25 年度外 国人留学生在籍状況調查結果, 2014.

4 ) Jackson, S. et al., Recent Research on Team and Organizational Diversity : SWOT Analysis and Implications, Journal of Management, Vol.29, pp.801-830, 2003.

5 ) Fleming, L., Perfecting cross-pollination. Harvard Business Review, 82 (9), pp.22-24, 2004.

6 ) Taylor H. Cox \& Stacy Blake. Managing cultural diversity: Implications for organizational competitiveness, The Academy of Management Executive, 5(3), pp.45-56, 1991.

7 ）日本規格協会, ISO 26000：2010 Guidance on social responsibility「社会的責任に関する手 引」, 2010.

8 ) 谷口真美; 組織におけるダイバーシティ・マ ネジメント, 特集 雇用平等とダイバーシティ, 日本労働研究雑誌, 50 (5), pp.69-84, 2008.

9 ）馬越恵美子；ダイバーシティ・マネジメント と異文化経営：グローバル人材を育てるマイ ンドウェアの世紀, 新評論, 2011.

10) NTTコム オンライン•マーケティング・ソリュー ション株式会社,「ダイバーシティ・マネジメ ント」に関する調査結果, Retrieved 1, 2013, from http : //research.goo.ne.jp/database/ data/001205/, 2010.

11）プラチナ社会研究会・レガシー共創協議会, 「2020年東京オリンピック・パラリンピック競 技大会レガシー」に関する提言（中間報告）, 2014.

12）永浜明子；アダプテッド・スポーツ体験によ る大学生の意識変化に関する事例報告（第 II 報）ーアダプテッド・スポーツ導入に向けた 授業自己評価の観点から - 大阪教育大学紀要 第 $\mathrm{V}$ 部門, 60 (2), pp.31-44, 2012.

13）秋政邦江, 小野擴男; 医療系大学における「健 康体育」授業への車いすダンスの導入 - ユニ バーサルスポーツの有効性一, 川崎医会誌一般 教, 36号, 2010. 
14）安井友康; 車いすバスケットボールの交流体 験が障害のイメージに与える影響, 障害者ス ポーツ科学, 2(1), pp.25-30, 2004.

15）NPOユニバーサルイベント協会, みんなが一緒 に参加できるユニバーサルスポーツの普及を めざして 第 1 編, 2002.

16）NPOユニバーサルイベント協会, みんなが一緒 に楽しめるユニバーサルスポーツを創造しょ う 第 2 編, 2002.

17）小林勉；開発戦略としてのスポーツの新たな 視点:「正統性」をめぐる組織と「現場」の問題, 体育学研究45, pp.707-718, 2000.

18) World Health Organization, \& JKYB研究会, Whoライフスキル教育プログラム, 大修館書 店, 1997.

19）菊池章夫; 思いやりを科学する-向社会的行 動の心理とスキル-, 川島書店, 1988.

20) Maythew S. Montei, et al., Validity of Scores on the Attitudes toward Diversity Scale (ATDS), Educational and Psychological Measurement, April 56 : pp.293-303, 1996

21) Helen A. Neville, et al. Construction and initial validation of the color-blind racial attitudes scale (CoBRAS), Journal of Counseling Psychology, 47 (1), pp.59-70, 2000.

22）上野耕平, 中込四郎 ; 運動部活動への参加によ る生徒のライフスキル獲得に関する研究,体育 學研究, 43(1), pp.33-42, 1998.

23）大信真人, 他 ; サッカー選手のライフスキル評 価尺度の開発一アイデンティティ及び特性的 自己効力感との関連から, 日本大学文理学部人 文学研究所, 研究紀要 (81), pp.81-89, 2011.
24）飯田順子・石隈利紀; 中学生の学校生活スキ ルに関する研究：学校生活スキル尺度（中学 生版）の開発, 教育心理学研究, 50 (2), pp.225236, 2002.

25）飯田順子, 他; 高校生の学校生活スキルに関す る研究一学校生活スキル尺度（高校生版）の 開発, 学校心理学研究, 9(1), pp.25-35, 2009.

26）アレックス・オスボーン =著, 豊田晃 $=$ 訳 ; 創 造力を生かすーアイデイアを得る38の方法, 創 元社, 2008 .

27）前野隆司；システム×デザイン思考で世界を 変える一慶應SDM「イノベーションのつくり 方」. 日経BP社, 2014.

28）浦上昌則, 脇田貴文; 心理学・社会科学研究の ための 調查系論文の読み方, 東京図書, 2008.

29) JF Hair, et al., Multivariate data analysis [Monograph] -6th ed., 2006.

30）ナレッシュ・K・マルホトラ, 他 ; マーケティ ング・リサーチの理論と実践, 同友館, 2006.

31）小塩真司；SPSS とAmosによる心理·調查デー 夕解析：因子分析・共分散構造分析まで, 東京 図書, 2004 .

32）小塩真司 ; SPSS とAmosによる心理・調查デー 夕解析：因子分析・共分散構造分析まで（第 2 版 ed.), 東京図書, 2011.

33）日本ブラインドサッカー協会. スポ育プロジェ クト. Retrieved 1, 2013, from http : //supoiku. b-soccer.jp/

34）狩野裕；構造方程式モデリングは，因子分析, 分散分析, パス解析のすべてにとって代わるの か?, 行動計量学 第29巻第 2 号, pp.138-159, 2002. 